\title{
polı, a remarkably error-prone human DNA polymerase
}

\author{
Agnès Tissier, ${ }^{1}$ John P. McDonald, ${ }^{1}$ Ekaterina G. Frank, and Roger Woodgate ${ }^{2}$ \\ Section on DNA Replication, Repair, and Mutagenesis, National Institute of Child Health and Human Development, \\ Bethesda, Maryland 20892-2725 USA
}

\begin{abstract}
The Saccharomyces cerevisiae RAD30 gene encodes DNA polymerase $\eta$. Humans possess two Rad30 homologs. One $(R A D 30 A / P O L H)$ has previously been characterized and shown to be defective in humans with the Xeroderma pigmentosum variant phenotype. Here, we report experiments demonstrating that the second human homolog $(R A D 30 B)$, also encodes a novel DNA polymerase that we designate polt. polt, is a distributive enzyme that is highly error-prone when replicating undamaged DNA. At template G or C, the average error frequency was $\sim 1 \times 10^{-2}$. Our studies revealed, however, a striking asymmetry in misincorporation frequency at template $A$ and $T$. For example, template $A$ was replicated with the greatest accuracy, with misincorporation of $G, A$, or $C$ occurring with a frequency of $\sim 1 \times 10^{-4}$ to $2 \times 10^{-4}$. In dramatic contrast, most errors occurred at template $T$, where the misincorporation of $G$ was, in fact, favored $\sim 3: 1$ over the correct nucleotide, $A$, and misincorporation of $T$ occurred at a frequency of $\sim 6.7 \times 10^{-1}$. These findings demonstrate that polı is one of the most error-prone eukaryotic polymerases reported to date and exhibits an unusual misincorporation spectrum in vitro.
\end{abstract}

[Key Words: DNA polymerase $\eta$; Rad30; Rad30B; somatic hypermutation; Xeroderma pigmentosum variant] Received April 6, 2000; revised version accepted May 10, 2000.

All organisms duplicate their genomic DNA using a highly processive and accurate DNA polymerase (Kornberg and Baker 1992; Kelman and O'Donnell 1995; Hubscher et al. 2000). In addition to their main replicase, many organisms possess additional DNA polymerases that fulfill vital roles in DNA synthesis and/or in DNA repair. Recently, a new class of DNA polymerase has been reported that appears to be used to replicate genomic DNA when the cell's replicase is unable to do so (Tang et al. 1998, 1999, 2000; Reuven et al. 1999; Johnson et al. 1999c; Masutani et al. 1999a; Wagner et al. 1999; Woodgate 1999). Indeed, it is thought that the primary role of this so-called UmuC/DinB/Rev1/Rad30 super-family of DNA polymerases is to facilitate translesion DNA synthesis of otherwise replication-blocking lesions. However, it is very likely that they are also capable of acting on undamaged DNA (Fijalkowska et al. 1997; Tang et al. 1998, 2000; Wagner et al. 1999; MaorShoshani et al. 2000). Whether this mode of replication is considered error-free or error-prone depends on the polymerase used and/or the particular DNA lesion encountered. Some, like the $\mathrm{UmuD}_{2}{ }_{2} \mathrm{C}$ complex (Escherichia coli pol V) are intrinsically error-prone whereas others, like Saccharomyces cerevisiae and human poln, are considered to be error-free when they perform translesion

\footnotetext{
${ }^{1}$ These authors contributed equally to this paper.

${ }^{2}$ Corresponding author.

E-MAIL woodgate@helix.nih.gov; FAX (301) 594-1135.
}

replication of a cis-syn thymine-thymine dimer or an acetylaminofluorene guanine (AAF-G) adduct (McDonald et al. 1997; Johnson et al. 1999c; Masutani et al. 1999b; Yuan et al. 2000; Washington et al. 2000).

The importance of this class of enzymes is obvious at both ends of the evolutionary spectrum. In E. coli, cells carrying a deletion of the umuDC operon are unable to bypass many types of lesions in single-stranded DNA (Szekeres et al. 1996; Lawrence et al. 1996; KoffelSchwartz et al. 1996; Napolitano et al. 1997) and, as a consequence, do not exhibit the large increase in mutagenesis normally seen in wild-type bacteria exposed to a variety of mutagens (Kato and Shinoura 1977; Steinborn 1978; Woodgate 1992). In addition, the spontaneous mutation rate in umuDC cells is also three- to fivefold lower than wild-type cells (Sargentini and Smith 1981; Woodgate 1992) indicating that E. coli polV also plays an important role in spontaneous mutagenesis. In humans, individuals expressing a severely truncated (and apparently inactive) pol $\eta$ are said to have the Xeroderma pigmentosum variant (XP-V) phenotype (Masutani et al. 1999b; Johnson et al. 1999a, 2000b). These patients exhibit sunlight sensitivity and a concomitant increased incidence of cancers (predominantly of the skin), and their cultured cells exhibit altered mutation spectra (Cleaver and Carter 1973; Wang et al. 1993; Raha et al. 1996; McGregor et al. 1999; Kuwamoto et al. 1999).

Recent phylogenetic studies suggest that many organisms possess multiple homologs of the UmuC/DinB/ 
Rev1/Rad30 family of DNA polymerases (McDonald et al. 1999; Gerlach et al. 1999; Ogi et al. 1999). For example, humans have at least four. These include a homolog of Rev1 (Lin et al. 1999); one is the aforementioned pol $\eta$ (encoded by the human $P O L H$ gene and also known as XPV and RAD30A); another is a second homo$\log$ of $S$. cerevisiae RAD30, termed $R A D 30 B$ (McDonald et al. 1999); finally, the last homolog is more closely related to the E. coli $\operatorname{din} B$ (pol IV) gene and has been called DINB1 (Gerlach et al. 1999; Ogi et al. 1999).

Given the relationship of the last two homologs to poln and pol IV, respectively, it seemed reasonable to predict that both the human $R A D 30 B$ and DINB1 genes encoded novel DNA polymerases (Woodgate 1999). Indeed, such an activity has very recently been shown for DINB1 (Johnson et al. 2000a; Ohashi et al. 2000). In this manuscript, we present data demonstrating that the $\mathrm{Rad} 30 \mathrm{~B}$ protein is also a DNA polymerase. After consultation with the Human Genome Organization (HUGO) nomenclature committee (http://www.gene.ucl.ac.uk/ nomenclature/l, it has been agreed that the $R A D 30 B$ gene should be renamed POLI (for DNA polymerase iota). We report here, an initial characterization of polı and demonstrate that the polymerase is highly errorprone when replicating undamaged DNA. Surprisingly, the fidelity of the enzyme was strongly influenced by the template nucleotide being replicated. Possible roles for this novel error-prone DNA polymerase within the cell are discussed.

\section{Results}

Overproduction and purification of wild-type and mutant polı

To test the hypothesis that Rad30B might possess intrinsic DNA polymerase activity, we fused the human $R A D 30 B$ gene in-frame with the glutathione S-transferase (GST) gene. The chimeric GST-Rad30B protein / 108 $\mathrm{kD})$ was expressed in insect cells and subsequently purified by GST-affinity and hydroxylapatite ion-exchange chromatography. We estimate that the purity of the GST-Rad30B fusion protein after these columns to be $>90 \%$ (Fig. 1A). However, it should be noted that we also observed small quantities of two lower molecular weight proteins in our preparation. We believe that these are amino-terminal proteolytic fragments of the fusion protein, as they were much more intense in earlier preparations that lacked protease inhibitors. Furthermore, they did not cross-react with antibodies raised to the carboxyl terminus of the Rad30B protein. Such truncations are apparently quite common in the Rad30-like polymerases as they were also observed in preparations of the related pol $\eta$ and polк enzymes (Masutani et al. 1999a; Ohashi et al. 2000). Fractions from the hydroxylapatite column were assayed for DNA polymerase activity and the fraction with the highest purity and greatest activity was used for subsequent studies (Fig. 1B). Replication was refractory to inhibition by aphidicolin $(100 \mu \mathrm{M})$, low levels of dideoxy nucleotides and low levels of N-ethylma-

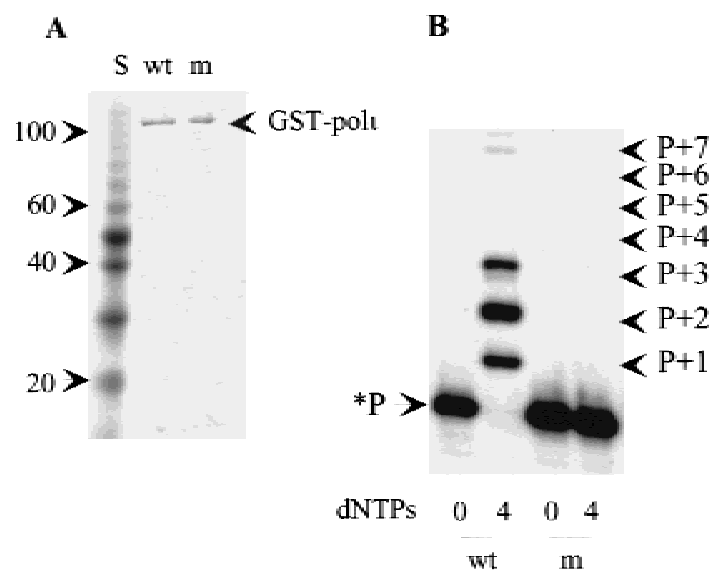

Figure 1. (A) Purity of wild-type and mutant forms of GSTtagged polı. Purified wild-type and mutant GST-tagged polı fusion proteins ( $250 \mathrm{ng})$ was run on a $4 \%-20 \%$ polyacrylamideSDS gel and visualized after staining with Coomassie brilliant blue R-250. (S) $10 \mathrm{kD}$ molecular weight protein ladder (Life Technologies, MD); the migration of the $20,40,60$, and $100 \mathrm{kD}$ markers are indicated at $l e f t ;(\mathrm{wt})$ wild-type GST-polı preparation used in the replication experiments; (m) D126A-E127A double alanine substituted mutant GST-polı protein. (B) DNA polymerase activity of the purified proteins. The position of the unextended radiolabeled primer $\left({ }^{\star} \mathrm{P}\right)$ as well as the products $(\mathrm{P}+1, \mathrm{P}+2$, etc. $)$ are noted at the side of the figure. Reaction mixes were incubated at $37^{\circ} \mathrm{C}$ for $30 \mathrm{~min}$ and assays were performed in the absence of dNTPs (0) or in the presence of all four dNTPs (4). The lack of any discernable primer degradation in the absence of dNTPs suggests that polı does not possess any 3'-5' exonucleolytic activity.

leimide (NEM; $100 \mu \mathrm{M}$ ) but was completely abolished in the presence of $1 \mathrm{~mm}$ NEM. To confirm that the polymerase activity is, in fact, intrinsic to the purified fusion protein, we were interested in analyzing a mutant variant that might lack the observed polymerase activity. Conserved motifs can be found in all of the UmuC/ DinB/Rev1/Rad30 superfamily of proteins (Kulaeva et al. 1996; McDonald et al. 1999; Masutani et al. 1999b; Johnson et al. 1999b) and, in particular, two adjacent invariant aspartate and glutamate residues within motif III are believed to be critical for the catalytic activity of these proteins, as they are most likely involved in the chelation of divalent $\mathrm{Mg}^{2+}$ ions necessary for polymerase activity (Kulaeva et al. 1996). In support of this hypothesis, mutations at these residues have been shown to result in a complete loss of polymerase activity in E. coli UmuC (Tang et al. 1999; Reuven et al. 1999), E. coli DinB (Wagner et al. 1999), S. cerevisiae Rad30 (Johnson et al. 1999 b,c) and human polк (Ohashi et al. 2000). As a consequence, we changed the appropriate Asp-126 and Glu127 residues of $R A D 30 B$ to alanine. The mutant Rad30B-GST fusion protein had similar physical properties to the wild-type protein and was purified to approximately the same degree after the GST- and hydroxylapatite columns (Fig. 1A). Unlike the wild-type protein, however, the mutant variant exhibited no DNA polymerase activity (Fig. 1B). Our observations suggest, 
therefore, that the polymerase activity observed with the wild-type protein is intrinsic to the chimeric GST$\operatorname{Rad} 30$ protein. We propose to rename $\operatorname{Rad} 30 \mathrm{~B}$ as DNA polymerase iota (polı) and the gene will henceforth be referred to as POLI.

\section{Polı is a highly error-prone DNA polymerase}

As noted above, in our replication assays, we found that in the presence of all four dNTPs polı extended the radiolabeled primer by an average of 2-3 nucleotides (Fig. 1B). In the absence of dNTPs there was no significant degradation of the annealed primer, suggesting that polı lacks any associated $3{ }^{\prime}-5^{\prime}$ exonucleolytic activity (Fig. 1B). Interestingly, closer inspection of the replication products $(\mathrm{P}+1, \mathrm{P}+2$, etc. $)$ revealed that each contained multiple gel bands corresponding to the slightly different electrophoretic mobility of each nucleotide added to the primer. This observation suggests that in addition to the correct nucleotide, polı is able to misincorporate incorrect nucleotides with relatively high efficiency. We investigated this further by performing reactions in the presence of individual dNTPs (Fig. 2). In these reactions, the respective oligonucleotide templates are virtually identical, differing only at the template nucleotide immediately downstream from the annealed primer (Fig. 2). This allows us to measure the incorporation of each nucleotide from the same "standing-start" primer. In most cases, it appeared that polı preferentially inserted the correct nucleotide opposite the complementary template base as was evident by the increased amount of primer utilization. However, there was also significant misincorporation of incorrect nucleotides at all template sites (Fig. 2). In particular, misincorporation of G at template $\mathrm{T}$ appeared to be better than, the correct nucleotide, A. polı also appears able to extend some of these mispairs. For example, in addition to correctly inserting $\mathrm{G}$ opposite $\mathrm{C}$, polı appeared to efficiently misincorporate
G opposite $\mathrm{T}$ and then extend this mispair by adding the correct next nucleotide of G opposite C (see Fig 2; dGTP track with template $\mathrm{C}$ ). This observation is quite remarkable as it means that polı can not only misinsert an incorrect base but is able to elongate from a mismatched base efficiently, a property not usually associated with a high fidelity enzyme.

To accurately determine the fidelity of polı, we used a steady-state gel assay that allows one to calculate the apparent $\mathrm{V}_{\max }$ and $\mathrm{K}_{\mathrm{m}}$ of the enzyme with respect to the enzyme's usage of the correct and incorrect nucleotide and thereby determine the frequency at which a misincorporation is likely to occur (Boosalis et al. 1987; Creighton et al. 1995) (Table 1). In these experiments, the same oligonucleotide templates used in Figure 2 were used and the ability of a limiting amount of polı to extend the primer in the presence of varying concentrations of each correct or incorrect dNTP was measured. Under these conditions, we found that for template A, G, and $\mathrm{C}$, incorporation of the correct nucleotide was favored over the incorrect nucleotide (Table 1). The exception was, quite strikingly, misinsertion of $\mathrm{G}$ opposite template $\mathrm{T}$, where the misinsertion was favored $\sim 3: 1$ over the correct nucleotide, A (Fig. 3; Table 1). Of all the mispairs, G.T is most readily formed (Mendelman et al. 1989|. However, misincorporation frequencies of G opposite $\mathrm{T}$ for most replicative polymerases are usually in the range of $10^{-3}$ to $10^{-5}$ (Mendelman et al. 1989) and it is certainly not favored over the correct nucleotide. Although as noted above, the correct nucleotide was generally favored over the incorrect dNTP at the remaining template sites, discrimination was particularly poor, with error frequencies generally ranging from $6.7 \times 10^{-1}$ for the $\mathrm{T} \cdot \mathrm{T}$ mispair to $6.3 \times 10^{-3}$ for the $\mathrm{A} \cdot \mathrm{C}$ mispair (Table 1). The exception was at template A, where polı appears to be relatively accurate, incorporating dTTP efficiently and misincorporating $G, A$, or $C$ at a frequency of $1 \times 10^{-4}$ to $2 \times 10^{-4}$ (Fig. 3; Table 1). The reason for this

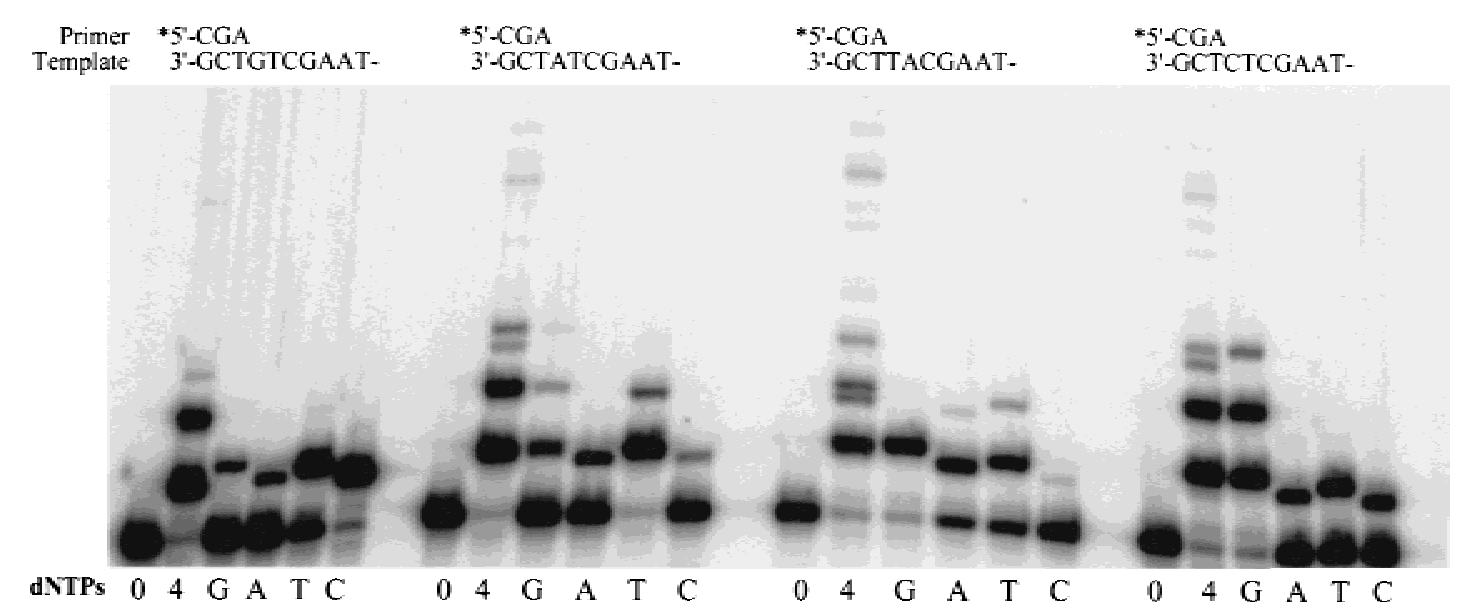

Figure 2. Ability of polı to incorporate nucleotides at various template sites. The extent of polı-dependent (mis)incorporation was measured at each template site in the absence (0) or presence of all four dNTPs (4) or presence of each individual dNTP (100 $\mu M)(G$, A, T, C). Reactions were for $30 \mathrm{~min}$ at $37^{\circ} \mathrm{C}$. The sequence context of each template is given above each panel. In particular, note the very efficient misincorporation of $G$ opposite $T$. 
Table 1. Fidelity of human polı as determined by steady state kinetics ${ }^{a}$

\begin{tabular}{|c|c|c|}
\hline dNTP $\cdot$ Template & $\begin{array}{c}V_{\max } / K_{m} \\
\left(\mathrm{M}^{-1} \mathrm{~min}^{-1}\right.\end{array}$ & $f_{\text {inc }}^{\mathrm{b}}$ \\
\hline $\mathrm{dGTP} \cdot \mathrm{G}$ & 0.005 & $6.5 \times 10^{-3}$ \\
\hline $\mathrm{dATP} \cdot \mathbf{G}$ & 0.02 & $2.2 \times 10^{-2}$ \\
\hline $\mathrm{dTTP} \cdot \mathbf{G}$ & 0.100 & $1.3 \times 10^{-1}$ \\
\hline $\mathrm{dCTP} \cdot \mathrm{G}$ & 0.76 & 1 \\
\hline $\mathrm{dGTP} \cdot \mathbf{A}$ & 0.008 & $1.0 \times 10^{-4}$ \\
\hline $\mathrm{dATP} \cdot \mathbf{A}$ & 0.02 & $2.0 \times 10^{-4}$ \\
\hline $\mathrm{dTTP} \cdot \mathbf{A}$ & 73.5 & 1 \\
\hline $\mathrm{dCTP} \cdot \mathbf{A}$ & 0.009 & $1.0 \times 10^{-4}$ \\
\hline dGTP·T & 0.33 & 3 \\
\hline dATP·T & 0.11 & 1 \\
\hline dTTP·T & 0.078 & $6.7 \times 10^{-1}$ \\
\hline $\mathrm{dCTP} \cdot \mathrm{T}$ & $\mathrm{nd}^{\mathrm{c}}$ & $<1.0 \times 10^{-5}$ \\
\hline $\mathrm{dGTP} \cdot \mathrm{C}$ & 3.0 & 1 \\
\hline $\mathrm{dATP} \cdot \mathrm{C}$ & 0.019 & $6.3 \times 10^{-3}$ \\
\hline $\mathrm{dTTP} \cdot \mathrm{C}$ & 0.023 & $7.7 \times 10^{-3}$ \\
\hline $\mathrm{dCTP} \cdot \mathrm{C}$ & 0.022 & $7.4 \times 10^{-3}$ \\
\hline
\end{tabular}

${ }^{a}$ The data were derived from experiments similar to that depicted in Fig. 3. However, in these experiments the length of the reaction time was varied considerably, to ensure that primer utilization was measurable in the inefficient reactions, yet was kept to $<20 \%$ in those that were more efficient. The reaction times were as follows: C, incorporation of dGTP was 2 min and of dATP, dTTP, or dCTP was $10 \mathrm{~min}$; T, incorporation of dGTP, dATP, or dTTP was 2 min and of dCTP was $10 \mathrm{~min}$; A, incorporation of dTTP was 2 min of dGTP or dATP was $10 \mathrm{~min}$, and of dCTP was $15 \mathrm{~min}$; $\mathrm{G}$, the reaction time for the incorporation of dCTP was 2 min and misincorporation of dGTP, dATP, and dTTP was $10 \mathrm{~min}$. Note that the $\mathrm{V}_{\max } / \mathrm{K}_{\mathrm{m}}$ is given in $\mathrm{M}^{-1} \mathrm{~min}^{-1}$, and therefore takes into account the differing reaction times.

${ }^{\mathrm{b}}$ The nucleotide misincorporation ratio, $f_{\text {inc }}=\left(\mathrm{V}_{\text {max }} / \mathrm{K}_{\mathrm{m}}\right)_{\text {incorrect }} /$ $\left(\mathrm{V}_{\max } / \mathrm{K}_{\mathrm{m}}\right)_{\text {correct }}$.

c(nd) Not detected.

accuracy is the especially high $\mathrm{V}_{\max }$ and low $\mathrm{K}_{\mathrm{m}}$ of dTTP incorporation opposite template A. Interestingly, the fact that polı prefers to use dTTP is also apparent at other template sites. With the exception of the G.T mispair noted above, the most frequent mispairs were $\mathrm{T} \cdot \mathrm{T}$ $\left(6.7 \times 10^{-1}\right)$ and $\mathrm{T} \cdot \mathrm{G}\left(1.3 \times 10^{-1}\right)$.

Thus, polı is highly error-prone compared to most replicative enzymes and even appears to have slightly lower fidelity than that recently reported for the related human poln (Matsuda et al. 2000). Perhaps the most striking aspect of these studies is the observation that the fidelity of polı is unusually template dependent, being relatively accurate at template A and highly inaccurate at the complementary template T. Nearest-neighbor effects on polymerase insertion fidelity have been observed with all enzymes studied to date (e.g., see Mendelman et al. 1989). It is likely, therefore, that the same will be true for polı. In an attempt to address this issue, we are presently analyzing the fidelity of polı at a variety of different template sites. It should be stressed, however, that any such nearest-neighbor effects are unlikely to change the major conclusion of this present work, namely that polı is a remarkably error-prone DNA polymerase. polı is a distributive enzyme

Based on our initial observations (Fig. 2) polı appears to be a distributive polymerase as even in the presence of relatively high levels of the enzyme and all 4 nucleotides, the primer was, on average, only extended 2-3 nucleotides. Although such properties would be consistent with the reported activities of the related poln and polк enzymes (Masutani et al. 1999a; Washington et al. 1999; Ohashi et al. 2000), we considered the possibility that this distributive mode of synthesis occurred as a result of the use of the relatively short synthetic oligonucleotide template $(40-\mathrm{mer})$ in the replication assays. To test this hypothesis, we compared the ability of polı to extend the same radiolabeled primer when annealed to a larger $(7.2 \mathrm{~kb})$, circular single-stranded template, M13mp19, or the linear 40-mer oligonucleotide. However, both the shorter oligonucleotide template and the larger M13 DNA gave qualitatively similar results with the primer only extended 2-3 nucleotides.

The ability of polı to accurately incorporate $\mathrm{T}$ opposite template A (Fig. 3; Table 1) prompted us to investigate whether this propensity might affect the distributive nature of polı. To examine this possibility, we synthesized a new 40-mer oligonucleotide template that contained a short run of six As immediately downstream from the primer and assayed the ability of decreasing amounts of polı to extend a fixed amount of primer-template [either the wild-type or poly(A) template] (Bambara et al. 1995; Fig. 4). Under conditions where we had a twofold molar excess of enzyme to primer/template, we only observed

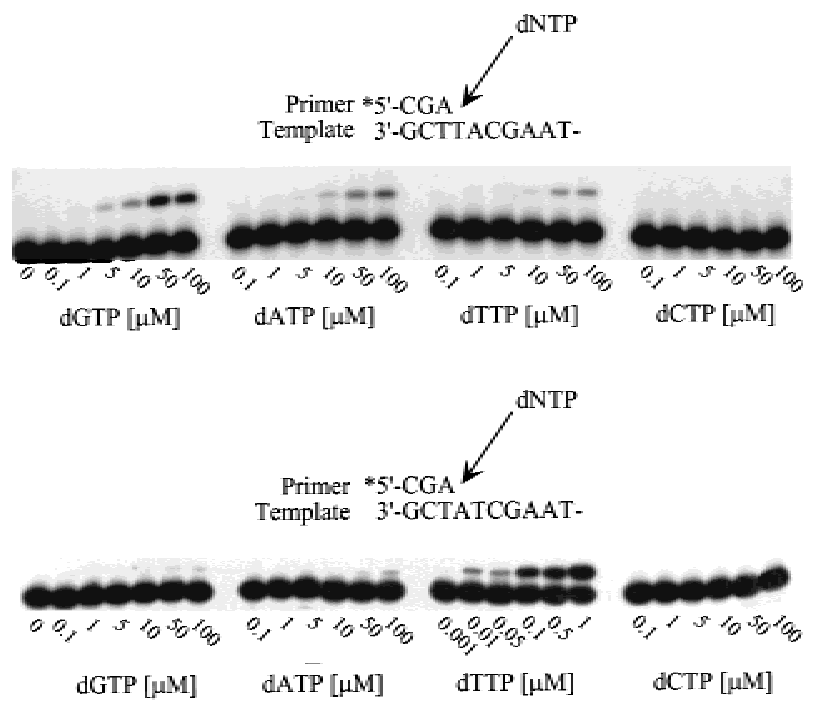

Figure 3. Kinetic analysis of polı-dependent (mis)incorporation at template $\mathrm{T}$ and template $\mathrm{A}$. The ability of polı to incorporate the correct or incorrect nucleotide at both template sites was assayed at varying concentrations of dNTPs in a 5-min reaction, to allow a direct visual comparison of (mis)insertion fidelity. In most cases, the dNTP concentration varied from 0.1 to $100 \mu \mathrm{M}$. The exception was the incorporation of dTTP opposite template A, where the range was $1 \mathrm{~nm}$ to $1 \mu \mathrm{M}$. The sequence context of each template is given above each respective panel. 
Tissier et al.

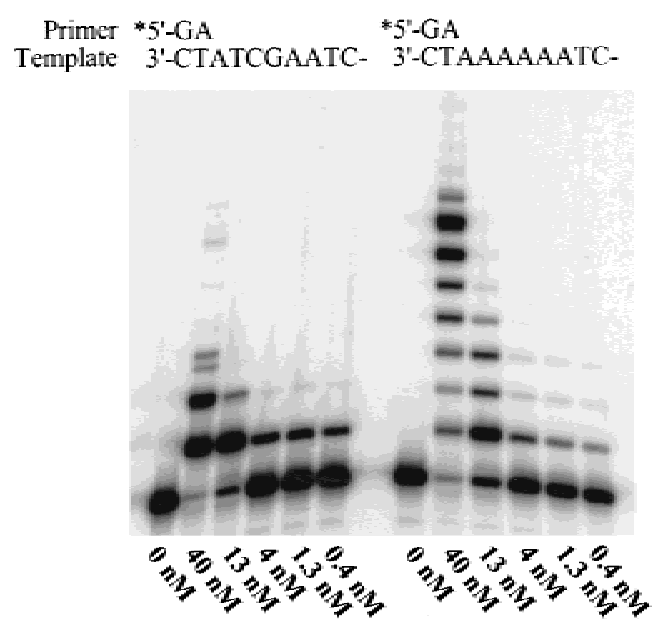

Figure 4. polı is a distributive enzyme. The ability of polı to extend the primer annealed to the wild-type template or the poly(A) template was assayed over a range of primer/template to enzyme concentrations. The primer/template was kept fixed at $20 \mathrm{~nm}$ and the enzyme varied from $40 \mathrm{~nm}$ to $0.4 \mathrm{~nm}$ as indicated. Reactions contained all four dNTPs (100 $\mu \mathrm{M}$ each) and were performed for $30 \mathrm{~min}$ at $37^{\circ} \mathrm{C}$.

the addition of three nucleotides with the wild-type template but eight with the poly(A) template. Interestingly, the replication pattern observed on the poly(A) track in the presence of all four dNTPs or dTTP alone was virtually identical, suggesting that polı preferentially used dTTP even when given a pool of dNTPs. Despite the fact that synthesis was clearly much more efficient than on the wild-type template, it still appeared distributive as is evident by the appearance of pause sites at each template A replicated. At lower enzyme to primer/template ratios, we only observed the addition of a single nucleotide on the wild-type template, but faint bands were visible at $\mathrm{P}+2$ and $\mathrm{P}+3$ with the poly(A) template (Fig. 4). Thus, polı is a distributive enzyme, but the number of nucleotides replicated in one binding/extension event appears to be template dependent, varying from 1 to 3 nucleotides.

\section{Discussion}

\section{Preliminary characterization of human polı}

Based on the homology of the deduced primary amino acid sequence of the POLI (RAD30B) gene to S. cerevisiae RAD30 and human POLH (RAD3OA/XPV) we previously hypothesized that it would encode a novel DNA polymerase (McDonald et al. 1999). The experiments outlined in this paper support such an hypothesis and detail the preliminary characterization of human DNA polymerase iota. Based on these findings, we believe that polı is unlike any other human DNA polymerase reported to date, in that it is an extraordinarily low-fidelity enzyme. Remarkably, at template $\mathrm{T}$, polı prefers to misinsert $\mathrm{G}$ rather than the "Watson-Crick" complementary base, A. At template G, T, or C, most mispairs occur with a frequency ranging from $6.7 \times 10^{-1}$ to $6.3 \times 10^{-3}$. One interesting property of polı is its preferred utilization of dTTP. As a consequence, misincorporations at template A are relatively rare compared to other sites, occurring in the range of $1 \times 10^{-4}-2 \times 10^{-4}$ which is similar to other DNA polymerases such as pol $\alpha$ (Mendelman et al. 1989, 1990) or pol $\beta$ (Boosalis et al. 1989; Chagovetz et al. 1997).

polı is a highly distributive enzyme, meaning that the activity of this error-prone polymerase is likely to be limited to just 1-2 base pairs. However, the apparent enzyme activity also appears to be strongly stimulated by the template sequence, with the greatest activity on short homopolymeric runs of template A (Fig. 4). By comparison, we have also noticed that when replicating templates with a random DNA sequence, polı tends to pause/dissociate more frequently at template $\mathrm{G}$ than at any other base (Fig. 2, cf. templates with all 4 dNTPs).

\section{Speculations as to a cellular role for error-prone polı}

In general, cells prefer to use a highly accurate DNA polymerase to replicate their DNA, so they presumably must possess a variety of mechanisms to limit the activity of polı in vivo. Conceivably, such regulation might occur through additional protein-protein interactions (that are lacking in our in vitro assay) that could increase its in vivo fidelity. Alternatively, the in vivo activity of polı may be strictly limited by targeting the enzyme for rapid proteolytic degradation. Such regulation may, in fact, be common to Rad30-like enzymes, as in addition to polı (Fig. 1), the related pol $\eta$ and polk also appear susceptible to proteolysis (Masutani et al. 1999a; Ohashi et al. 2000). Given the fact that homologs of human POLI have been identified in many higher eukaryotes including mice (McDonald et al. 1999) and the recently sequenced Drosophila melanogaster genome (Adams et al. 2000), the presence of error-prone POLI must presumably provide some evolutionary advantage to these organisms. Indeed, there are special cases where a lowfidelity polymerase might be useful. A good example is the generation of mutations in the variable region of human immunoglobulin ( $\mathrm{IgV})$ genes, as it would provide the necessary genetic diversity required for an efficient immune response. The mechanism of this somatic hypermutability is still poorly understood (for recent reviews, see Harris et al. 1999; Spencer and Dunn-Walters 1999). However, it does not seem to require nucleotide excision repair (Jacobs et al. 1998) and mismatch repair appears to operate after the mutational event rather than cause it (Winter et al. 1998; Kim et al. 1999). The prevailing model is that the hypermutability occurs as a result of the action of an error-prone DNA polymerase (Diaz and Flajnik 1998; Diaz et al. 1999). Interestingly, the error-rate over the 1.5-2 kb variable region in rearranged IgV gene is estimated to be between $10^{-2}$ and $10^{-3}$ and is certainly within the range of that described here for polı. In general, transitions are favored 2:1 over transversions, but perhaps more importantly, there is a strand bias in that mutations from $\mathrm{T}$ occur with a much lower 
frequency than the complementary A (Yelamos et al. 1995; Smith et al. 1996). Such findings have previously been thought to indicate a requirement for transcription in the hypermutability process (Yelamos et al. 1995). We would like to suggest, however, that an involvement of error-prone polı in the generation of somatic hypermutations might help explain this strand bias. For example, our observation that polı is relatively accurate when replicating template A means that fewer mutations from $\mathrm{T}$ will occur, whereas the fact that polt is much more errorprone when replicating template $\mathrm{T}$, means that there are likely to be many more mutations from A. Furthermore, the fact that under certain conditions polı is also able to extend one or more mispaired nucleotides (Fig. 2), suggests that it might also contribute to the tandem mutations observed in the $\operatorname{IgV}$ gene that are revealed in mismatch-repair deficient mice (Winter et al. 1998).

Another hypothesis is that somatic hypermutability requires separate AT/GC mutators (Spencer et al. 1999). Based on a recent literature search, humans now appear to possess at least 12 DNA polymerases. Many of these are considered to be error-prone and might also be candidates for one of the aforementioned mutators. The best studied is pol $\beta$, which although required for base-excision repair does not appear to be involved in somatic hypermutation (Esposito et al. 2000). Although S. cerevisiae pol $\zeta$ is error-prone when replicating damaged DNA (Nelson et al. 1996), the human equivalent has yet to be characterized. Human pol $\eta$ is also apparently error-prone on undamaged DNA (Johnson et al. 2000b; Matsuda et al. 2000), however humans with defects in poln (XP-V patients), apparently do not exhibit any major immunological defect, suggesting that like pol $\beta$, pol $\eta$ is not involved in somatic mutagenesis. Other potential candidates for the presumed error-prone polymerase appear to be the recently described polк (Ohashi et al. 2000), the polß-like enzyme, pold (Genbank accession no. AJ131890) and the terminal-transferase-like, pol $\mu$ (Dominguez et al. 2000). Although in vitro experiments provide clues as to the involvement of error-prone DNA polymerases in this fascinating process, a more definitive answer will clearly be found in transgenic mice that lack polı or one of the aforementioned error-prone DNA polymerases and such experiments are currently in progress in a number of laboratories.

Another possible role for polı is that of a back-up to

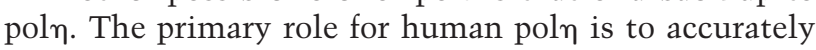
replicate the major UV-induced DNA lesion, a cis-syn T-T dimer (Masutani et al. 1999a,b; Washington et al. 2000). Humans lacking pol $\eta$ show a greatly reduced capacity to replicate past the T-T dimer (Masutani et al. 1999a), but the little replication that does traverse the lesion is apparently error-prone, as XP-V patients exhibit an increased rate of cancers and cultured cells exhibit a very different mutation spectrum from wild-type cells. The majority of the mutations in XP-V cells are C-A and T-A transversions (Wang et al. 1993; McGregor et al. 1999). This would be consistent with incorporation of dTTP opposite the $\mathrm{C}$ or $\mathrm{T}$ of a pyrimidine dimer. polı appears to use dTTP efficiently and it will be interesting to determine if such a preference is observed at cis-syn pyrimidine dimers, if so, it is possible that polı is the DNA polymerase that generates the mutations that ultimately lead to a higher rate of cancers in XP-V patients.

\section{Materials and methods}

Overproduction of wild-type and mutant forms of GST-tagged polı

The baculovirus expression vector used in these studies was pAcG2T (PharMingen, La Jolla, CA). A chimeric GST-POLI gene was constructed by first synthesizing two oligonucleotides pAcG2T5, 5'-CGGGATCCCAGGCCTGG GCCATGGACCCGGGCGTACGTCGACCTGCAGAATTCCG-3' and pAcG2T6, 5'-CGGAATTCTGCAGGTCGACGTACGCCCGGGTCCATGGCCCAGGCCTGGGATCCCG-3' that when annealed form a 55-mer with unique BamHI, EcoRI, and NcoI restriction enzymes sites (NcoI underlined). The annealed oligonucleotides were digested with BamHI and EcoRI and ligated into the similarly digested pAcG2T vector to create pJM296. An in-frame GST-POLI fusion was generated by cloning an $\sim 2.4-\mathrm{kb} N c o$ I to PstI fragment of human POLI (formerly RAD30B) from clone 6-1 (McDonald et al. 1999) (Genbank accession no. AF140501) into NcoI-PstI-digested pJM296 to create pJM299. A mutant form of the GST-POLI gene was constructed by using the Quick Change mutagenesis kit (Stratagene, La Jolla, CA). Adjacent residues, D126 and E127 in POLI where changed to A126-A127 in clone 6-1 using primers R30AAA, 5'-CTTGGATTTGCTGCCAATTTTGTGGATCTA-3' and R30AAB, 5'-CACAAAATTGGCAGCAAATCCAAGTCTCTC-3' to create plasmid pJM300. For the convenience of subsequent identification, these primers also contain silent changes that result in a novel $B s t X I$ restriction enzyme site (underlined). An $\sim 0.28-\mathrm{kb} B s t \mathrm{EII}$ to $B s t Z 17 I$ fragment from pJM300 was sequenced to verify that the region only contained the desired mutation and then subcloned into the similarly digested wild-type GST-POLI expression vector, pJM299, to create pJM302, which expresses the nonfunctional mutant POLI-GST protein.

\section{Purification of wild-type and mutant forms of GST-tagged polı}

SF9 insect cells ( 1 liter) (PharMingen) were infected at a multiplicity of infection (M.O.I) of 3 with a high-titer stock of either pJM299- or pJM302-derived baculovirus. After $60 \mathrm{hr}$ incubation, the cell pellet was recovered by centrifugation and lysed on ice for $45 \mathrm{~min}$ in $50 \mathrm{ml}$ of Insect lysis buffer (PharMingen) containing $1 \times$ Protease inhibitor cocktail (PharMingen). After cell lysis, the mixture was centrifuged at 45,000 rpm in a Beckman $50.2 \mathrm{Ti}$ rotor for $1 \mathrm{hr}$. The supernatant was incubated with $4 \mathrm{ml}$ of Glutathione-Agarose (PharMingen), equilibrated with $1 \times$ PBS containing $0.01 \% \mathrm{NP}-40$, by rotating at $4^{\circ} \mathrm{C}$ for $2 \mathrm{hr}$. The matrix was subsequently packed into a disposable column, washed with 10 column volumes of A-buffer $(20 \mathrm{~mm}$ Tris- $\mathrm{HCl}$ at $\mathrm{pH} 8.0$, $1 \mathrm{M} \mathrm{NaCl}, 10 \mathrm{~mm}$ 2-mercaptoethanol, $0.01 \% \mathrm{NP}-40$ ) and 10 column volumes of B-buffer ( $1 \times$ PBS, 10 mM 2-mercaptoethanol, $0.01 \% \mathrm{NP}-40)$ at $4^{\circ} \mathrm{C}$. The GST-polı fusion protein was eluted from the GST column in a stepwise fashion by washing with 4 column volumes of E-buffer (50 mM Tris- $\mathrm{HCl}$ at $\mathrm{pH}$ 8.0, $20 \mathrm{~mm}$ reduced Glutathione (Sigma, MO), $100 \mathrm{~mm} \mathrm{NaCl,} 10 \mathrm{~mm}$ 2-mercaptoethanol, $0.01 \% \mathrm{NP}-40$ ). The GST-polı containing eluate was applied to a hydroxylapatite (BioRad, CA) column, equilibrated with P-buffer (10 mM Na-phosphate at $\mathrm{pH} 7.7,100 \mathrm{~mm}$ $\mathrm{NaCl}, 10 \mathrm{~mm}$ 2-mercaptoethanol). The column was subse- 
quently washed with 10 column volumes of P-buffer and the GST-polı fusion protein eluted with a 10-200 mM linear gradient of Na-phosphate in P-buffer. Finally, glycerol was added to the GST-polı containing fractions $(10 \% \mathrm{vol} / \mathrm{vol})$ prior to storing at $-80^{\circ} \mathrm{C}$.

\section{DNA templates}

All synthetic oligonucleotides were synthesized by Loftstrand Laboratories (Gaithersburg, MD) using standard techniques and were gel purified prior to use. The templates for the replication reactions were designed such that a universal 16-mer primer, 5'-CTTGAAAACATAGCGA-3', could be used in all of the replication reactions. The primer was $5^{\prime}$-labeled with $\left[\gamma^{-32} \mathrm{P}\right] \mathrm{ATP}$ (5000 Ci/mmole; $1 \mathrm{Ci}=37 \mathrm{GBq}$ ) (Amersham Pharmacia Biotech, Piscataway, NJ) using T4 polynucleotide kinase (Life Technologies, Gaithersburg, MD). All synthetic oligonucleotide templates were 40mers in length. The sequence of the wild-type template was 5'-AGCGTCTTAATCTAAGCTATCGCTATGTTTTCAAGGATTC-3'. This sequence corresponds to nucleotides $4072-4121$ of M13mp18. The nucleotides underlined indicate the location of the annealed universal primer (Fig. 1B). This template was also used to measure the fidelity of nucleotide insertion at template A (Figs. 2 and 3). To measure the fidelity of nucleotide insertion at template $G, C$, or $T$, similar oligonucleotides were synthesized but which contained $\mathrm{G}$ or $\mathrm{C}$ at nucleotide 19 of the 40 mer template or AT at nucleotides 18-19 of the template (Figs. 2 and 3). Similarly, a template with a run of six As immediately downstream of the primer was synthesized by replacing nucleotides 16-18 of the wild-type template with A (Fig. 4).

\section{Replication reactions}

Radiolabeled primer-template DNAs were prepared by annealing the $5^{\prime}-{ }^{32} \mathrm{P}$-labeled 16 -mer universal primer to the unlabeled template DNA at a molar ratio of 1:1.5. Standard reactions of 10 $\mu l$ contained $40 \mathrm{~mm}$ Tris- $\mathrm{HCl}$ at $\mathrm{pH} 8.0,5 \mathrm{~mm} \mathrm{MgCl}_{2}, 100 \mu \mathrm{M}$ of each ultrapure dNTP (Amersham Pharmacia Biotech, NJ), 10 mм DTT, $250 \mu \mathrm{g} / \mathrm{ml} \mathrm{BSA,} 60 \mathrm{~mm} \mathrm{KCl}, 2.5 \%$ glycerol, 20-30 nм $5^{\prime}-\left[{ }^{32} \mathrm{P}\right]$ primer-template DNA and 3 nM GST-Polı. After incubation at $37^{\circ} \mathrm{C}$ for $30 \mathrm{~min}$, reactions were terminated by the addition of $10 \mu \mathrm{l}$ of $95 \%$ formamide/10 mM EDTA and the samples heated to $100^{\circ} \mathrm{C}$ for $5 \mathrm{~min}$. Reaction mixtures $(5 \mu \mathrm{l})$ were subjected to $20 \%$ polyacrylamide/ 7 m Urea gel electrophoresis and replication products visualized by autoradiography or PhosphorImager analysis.

\section{Kinetic analysis of replication products}

Time course reactions using the standard replication conditions were initially performed so as to ensure that the reaction was in the linear range (usually $<20 \%$ of primer utilization) (Boosalis et al. 1987; Creighton et al. 1995). Subsequent reactions measuring the incorporation of the correct nucleotide were performed for 2-5 min, whereas those measuring the incorrect nucleotide were for 5, 10, or $15 \mathrm{~min}$. In most cases, the concentration of the single correct or incorrect nucleotide in the reaction mixture varied from $0.1 \mu \mathrm{M}$ to $100 \mu \mathrm{M}$. The exceptions were in the analysis of the incorporation of $\mathrm{G}$ opposite template $\mathrm{C}$, where the concentration of dGTP was varied from $10 \mathrm{nM}$ to $10 \mu \mathrm{M}$ and also in the analysis of the correct incorporation of dTTP at template A, where the concentration of dTTP was varied from $1 \mathrm{nM}$ to 1 $\mu \mathrm{M}$. All of the reactions use the same standing-start primer and reactions were initiated by the addition of the appropriate dNTP. Reaction products were separated in a $20 \%$ polyacryl- amide gel containing $7 \mathrm{M}$ urea and gels dried prior to quantitative PhosphorImager analysis using the ImageQuant software (Molecular Dynamics, CA). Saturation plots of velocity as a function of dNTP concentration were determined by dividing the percent of product generated by the respective reaction time of the reaction. The apparent $\mathrm{V}_{\max }$ and $\mathrm{K}_{\mathrm{m}}$ values were derived from nonlinear least squares fits to a rectangular hyperbola using the Sigma Plot software (SPSS, Chicago, IL). Nucleotide misincorporation frequencies were subsequently calculated using the formula: $f_{\text {inc }}=\left(\mathrm{V}_{\text {max }} / \mathrm{K}_{\mathrm{m}}\right)_{\text {incorrect }} /\left(\mathrm{V}_{\max } / \mathrm{K}_{\mathrm{m}}\right)_{\text {correct }}$ as described previously (Boosalis et al. 1987; Creighton et al. 1995).

\section{Acknowledgments}

This work was supported in by the NIH Intramural research program. We would like to thank Myron Goodman, Sandra Randall, and Mengjia Tang for advice and help with the analysis of the kinetic-gel assay; Luis Blanco and Haruo Ohmori for sharing unpublished data prior to publication; and Martín Gonzalez, Antonio Rodriguez, Mary McLenigan, Dominique Vandewiele, and François Boudsocq for helpful comments and suggestions during the course of this work.

The publication costs of this article were defrayed in part by payment of page charges. This article must therefore be hereby marked "advertisement" in accordance with 18 USC section 1734 solely to indicate this fact.

\section{References}

Adams, M.D., Celniker, S.E., Holt, R.A., Evans, C.A., Gocayne, J.D., Amanatides, P.G., Scherer, S.E., Li, P.W., Hoskins, R.A., Galle, R.F. et al. 2000. The genome sequence of Drosophila melanogaster. Science 287: 2185-2195.

Bambara, R.A., Fay, P.J., and Mallaber., L.M. 1995. Methods of analyzing processivity. Methods Enzymol. 262: 270-280.

Boosalis, M.S., Petruska, J., and Goodman, M.F. 1987. DNA polymerase insertion fidelity. Gel assay for site-specific kinetics. J. Biol. Chem. 262: 14689-14696.

Boosalis, M.S., Mosbaugh, D.W., Hamatake, R., Sugino, A., Kunkel, T.A., and Goodman, M.F. 1989. Kinetic analysis of base substitution mutagenesis by transient misalignment of DNA and by miscoding. J. Biol. Chem. 264: 11360-11366.

Chagovetz, A.M., Sweasy, J.B., and Preston, B.D. 1997. Increased activity and fidelity of DNA polymerase $\beta$ on singlenucleotide gapped DNA. J. Biol. Chem. 272: 27501-27504.

Cleaver, J.E. and Carter, D.M. 1973. Xeroderma pigmentosum variants: Influence of temperature on DNA repair. J. Invest. Dermatol. 60: 29-32.

Creighton, S., Bloom, L.B., and Goodman, M.F. 1995. Gel fidelity assay measuring nucleotide misinsertion, exonucleolytic proofreading, and lesion bypass efficiencies. Methods Enzymol. 262: 232-256.

Diaz, M. and Flajnik, M.F. 1998. Evolution of somatic hypermutation and gene conversion in adaptive immunity. Immunol. Rev. 162: 13-24.

Diaz, M., Velez, J., Singh, M., Cerny, J., and Flajnik, M.F. 1999. Mutational pattern of the nurse shark antigen receptor gene (NAR) is similar to that of mammalian Ig genes and to spontaneous mutations in evolution: The translesion synthesis model of somatic hypermutation. Int. Immunol. 11: 825833.

Dominguez, O., Ruiz, J.F., Lain De Lera, T., Garcia-Diaz, M., Gonzalez, M.A., Kirchhoff, T., Martinez-A, C., Bernad, A. and Blanco, L. 2000. DNA polymerase mu (Pol $\mu$ ), homologous to TdT, could act as a DNA mutator in eukaryotic cells. EMBO I. 19: 1731-1742. 
Esposito, G., Texido, G., Betz, U.A., Gu, H., Muller, W., Klein, U., and Rajewsky, K. 2000. Mice reconstituted with DNA polymerase $\beta$-deficient fetal liver cells are able to mount a $\mathrm{T}$ cell-dependent immune response and mutate their Ig genes normally. Proc. Natl. Acad. Sci. 97: 1166-1171.

Fijalkowska, I.J., Dunn, R.L., and Schaaper, R.M. 1997. Genetic requirements and mutational specificity of the Escherichia coli SOS mutator activity. J. Bacteriol. 179: 7435-7445.

Gerlach, V.L., Aravind, L., Gotway, G., Schultz, R.A., Koonin, E.V., and Friedberg, E.C. 1999. Human and mouse homologs of Escherichia coli DinB (DNA polymerase IV), members of the UmuC/DinB superfamily. Proc. Natl. Acad. Sci. 96: 11922-11927.

Harris, R.S., Kong, Q., and Maizels, N. 1999. Somatic hypermutation and the three R's: Repair, replication and recombination. Mutat. Res. 436: 157-178.

Hubscher, U., Nasheuer, H.-P., and Syvaoja, J.E. 2000. Eukaryotic DNA polymerases, a growing family. Trends Biochem. Sci. 25: 143-147.

Jacobs, H., Fukita, Y., van der Horst, G.T., de Boer, J., Weeda, G., Essers, J., de Wind, N., Engelward, B.P., Samson, L., Verbeek, S. et al. 1998. Hypermutation of immunoglobulin genes in memory B cells of DNA repair- deficient mice. J. Exp. Med. 187: 1735-1743.

Johnson, R.E., Kondratick, C.M., Prakash, S., and Prakash, L. 1999a. hRAD30 mutations in the variant form of Xeroderma Pigmentosum. Science 285: 263-265.

Johnson, R.E., Prakash, S., and Prakash, L. 1999b. Requirement of DNA polymerase activity of yeast Rad30 protein for its biological function. J. Biol. Chem. 274: 15975-15977.

- 1999c. Efficient bypass of a thymine-thymine dimer by yeast DNA polymerase, poln. Science 283: 1001-1004.

- 2000a. The human DINB1 gene encodes the DNA polymerase Polo. Proc. Natl. Acad. Sci. 97: 3838-3843.

Johnson, R.E., Washington, M.T., Prakash, S., and Prakash, L. 2000b. Fidelity of human DNA polymerase $\eta$. J. Biol. Chem. 275: 7447-7450.

Kato, T. and Shinoura, Y. 1977. Isolation and characterization of mutants of Escherichia coli deficient in induction of mutations by ultraviolet light. Mol. Gen. Genet. 156: 121-131.

Kelman, Z. and O'Donnell, M. 1995. DNA polymerase III holoenzyme: Structure and function of a chromosomal replicating machine. Annu. Rev. Biochem. 64: 171-200.

Kim, N., Bozek, G. Lo, J.C., and Storb, U. 1999. Different mismatch repair deficiencies all have the same effects on somatic hypermutation: Intact primary mechanism accompanied by secondary modifications. J. Exp. Med. 190: 21-30.

Koffel-Schwartz, N., Coin, F., Veaute, X., and Fuchs, R.P.P. 1996. Cellular strategies for accommodating replication-hindering adducts in DNA: Control by the SOS response in Escherichia coli. Proc. Nat1. Acad. Sci. 93: 7805-7810.

Kornberg, A. and Baker, T.A. 1992. DNA replication. W.H. Freeman \& Co., New York, NY.

Kulaeva, O.I., Koonin, E.V., McDonald, J.P., Randall, S.K., Rabinovich, N., Connaughton, J.F., Levine, A.S., and Woodgate, R. 1996. Identification of a DinB/UmuC homolog in the archeon Sulfolobus solfataricus. Mutat. Res. 357: 245-253.

Kuwamoto, K., Miyauchi-Hashimoto, H., Isei, T., and Horio, T. 1999. Xeroderma pigmentosum variant associated with multiple cancers. Photodermatol. Photoimmunol. Photomed. 15: $127-132$.

Lawrence, C.W., Borden, A., and Woodgate, R. 1996. Analysis of the mutagenic properties of the UmuDC, MucAB and RumAB proteins, using a site specific abasic lesion. Mol. Gen. Genet. 251: 493-498.

Lin, W., Xin, H., Zhang, Y., Wu, X., Yuan, F., and Wang, Z. 1999.
The human REV1 gene codes for a DNA template-dependent dCMP transferase. Nucleic Acids Res. 27: 4468-4475.

Maor-Shoshani, A., Reuven, N.B., Tomer, G., and Livneh, Z. 2000. Highly mutagenic replication by DNA polymerase V (UmuC) provides a mechanistic basis for SOS untargeted mutagenesis. Proc. Nat1. Acad. Sci. 97: 565-570.

Masutani, C., Araki, M., Yamada, A., Kusumoto, R., Nogimori, T., Maekawa, T., Iwai, S., and Hanaoka, F. 1999a. Xeroderma pigmentosum variant (XP-V) correcting protein from HeLa cells has a thymine dimer bypass DNA polymerase activity. EMBO I. 18: 3491-3501.

Masutani, C., Kusumoto, R., Yamada, A., Dohmae, N., Yokoi, M., Yuasa, M., Araki, M., Iwai, S., Takio, K., and Hanaoka, F. $1999 \mathrm{~b}$. The XPV (xeroderma pigmentosum variant) gene encodes human DNA polymerase $\eta$. Nature 399: 700-704.

Matsuda, T., Bebenek, K., Masutani, C., Hanaoka, F., and Kunkel, T.A. 2000. Low fidelity DNA synthesis by human DNA polymerase- $\eta$. Nature 404: 1011-1013.

McDonald, J.P., Levine, A.S., and Woodgate, R. 1997. The Saccharomyces cerevisiae RAD30 gene, a homologue of Escherichia coli $\operatorname{din} B$ and $u m u C$, is DNA damage inducible and functions in a novel error-free postreplication repair mechanism. Genetics 147: 1557-1568.

McDonald, J.P., Rapic-Otrin, V., Epstein, J.A., Broughton, B.C., Wang, X., Lehmann, A.R., Wolgemuth, D.J., and Woodgate, R. 1999. Novel human and mouse homologs of Saccharomyces cerevisiae DNA polymerase $\eta$. Genomics 60: 20-30.

McGregor, W.G., Wei, D., Maher, V.M., and McCormick, J.J. 1999. Abnormal, error-prone bypass of photoproducts by xeroderma pigmentosum variant cell extracts results in extreme strand bias for the kinds of mutations induced by UV light. Mol. Cell. Biol. 19: 147-154.

Mendelman, L.V., Boosalis, M.S., Petruska, J., and Goodman, M.F. 1989. Nearest neighbor influences on DNA polymerase insertion fidelity. J. Biol. Chem. 264: 14415-14423.

Mendelman, L.V., Petruska, J., and Goodman, M.F. 1990. Base mispair extension kinetics. Comparison of DNA polymerase $\alpha$ and reverse transcriptase. J. Biol. Chem. 265: 2338-2346.

Napolitano, R.L., Lambert, I.B., and Fuchs, R.P.P. 1997. SOS factors involved in translesion synthesis. Proc. Natl. Acad. Sci. 94: 5733-5738.

Nelson, J.R., Lawrence, C.W., and Hinkle, D.C. 1996. Thyminethymine dimer bypass by yeast DNA polymerase. Science 272: 1646-1649.

Ogi, T., Kato, T., and Ohmori, H. 1999. Mutation enhancement by DINB1, a mammalian homologue of the Escherichia coli mutagenesis protein DinB. Genes Cells 4: 607-618.

Ohashi, E., Ogi, T., Kusumoto, R., Iwai, S., Masutani, C., Hanaoka, F., and Ohmori, H. 2000. Error-prone bypass of certain DNA lesions by the human DNA polymerase $\kappa$. Genes \& Dev. (this issue).

Raha, M., Wang, G., Seidman, M.M., and Glazer, P.M. 1996. Mutagenesis by third-strand-directed psoralen adducts in repair-deficient human cells: High frequency and altered spectrum in a xeroderma pigmentosum variant. Proc. Nat1. Acad. Sci. 93: 2941-2946.

Reuven, N.B., Arad, G., Maor-Shoshani, A., and Livneh, Z. 1999. The mutagenesis protein UmuC is a DNA polymerase activated by UmuD', RecA, and SSB and is specialized for translesion replication. J. Biol. Chem. 274: 31763-31766.

Sargentini, N.J. and Smith, K.C. 1981. Much of spontaneous mutagenesis in Escherichia coli is due to error-prone DNA repair: Implications for spontaneous carcinogenesis. Carcinogenesis 2: 863-872.

Smith, D.S., Creadon, G., Jena, P.K., Portanova, J.P., Kotzin, B.L., and Wysocki, L.J. 1996. Di- and trinucleotide target 
Tissier et al.

preferences of somatic mutagenesis in normal and autoreactive B cells. J. Immunol. 156: 2642-2652.

Spencer, J.O. and Dunn-Walters, D.K. 1999. Somatic hypermutation and B-cell malignancies. J. Pathol. 187: 158-163.

Spencer, J., Dunn, M., and Dunn-Walters, D.K. 1999. Characteristics of sequences around individual nucleotide substitutions in IgVH genes suggest different GC and AT mutators. J. Immunol. 162: 6596-6601.

Steinborn, G. 1978. Uvm mutants of Escherichia coli K12 deficient in UV mutagenesis. I. Isolation of uvm mutants and their phenotypical characterization in DNA repair and mutagenesis. Mol. Gen. Genet. 165: 87-93.

Szekeres Jr., E.S., Woodgate, R., and Lawrence, C.W. 1996. Substitution of $m u c A B$ or rum $A B$ for umuDC alters the relative frequencies of the two classes of mutations induced by a site-specific T-T cyclobutane dimer and the efficiency of translesion DNA synthesis. J. Bacteriol. 178: 2559-2563.

Tang, M., Bruck, I., Eritja, R., Turner, J., Frank, E.G., Woodgate, R., O'Donnell, M., and Goodman, M.F. 1998. Biochemical basis of SOS-induced mutagenesis in Escherichia coli: Reconstitution of in vitro lesion bypass dependent on the $\mathrm{UmuD}_{2} \mathrm{C}$ mutagenic complex and RecA. Proc. Natl. Acad. Sci. 95: 9755-9760.

Tang, M., Shen, X., Frank, E.G., O'Donnell, M., Woodgate, R., and Goodman, M.F. 1999. UmuD ${ }_{2} \mathrm{C}$ is an error-prone DNA polymerase, Escherichia coli, DNA pol V. Proc. Natl. Acad. Sci. 96: 8919-8924.

Tang, M., Pham, P., Shen, X., Taylor, J-S., O'Donnell, M., Woodgate, R., and Goodman, M. 2000. Roles of E. coli DNA polymerases IV and V in lesion-targeted and untargeted SOS mutagenesis. Nature 404: 1014-1018.

Wagner, J., Gruz, P., Kim, S.R., Yamada, M., Matsui, K., Fuchs, R.P.P., and Nohmi, T. 1999. The dinB gene encodes an novel Escherichia coli DNA polymerase (DNA pol IV) involved in mutagenesis. Mol. Cell 4: 281-286.

Wang, Y.C., Maher, V.M., Mitchell, D.L., and McCormick, J.J. 1993. Evidence from mutation spectra that the UV hypermutability of xeroderma pigmentosum variant cells reflects abnormal, error-prone replication on a template containing photoproducts. Mol. Cell. Biol. 13: 4276-4283.

Washington, M.T., Johnson, R.E., Prakash, S., and Prakash, L. 1999. Fidelity and processivity of Saccharomyces cerevisiae DNA polymerase $\eta$. J. Biol. Chem. 274: 36835-36838.

. 2000. Accuracy of thymine-thymine dimer bypass by Saccharomyces cerevisiae DNA polymerase $\eta$. Proc. Nat1. Acad. Sci. 97: 3094-3099.

Winter, D.B., Phung, Q.H., Umar, A., Baker, S.M., Tarone, R.E., Tanaka, K., Liskay, R.M. Kunkel, T.A., Bohr, V.A., and Gearhart, P.J. 1998. Altered spectra of hypermutation in antibodies from mice deficient for the DNA mismatch repair protein PMS2. Proc. Nat1. Acad. Sci. 95: 6953-6958.

Woodgate, R. 1992. Construction of a umuDC operon substitution mutation in Escherichia coli. Mutat. Res. 281: 221-225.

. 1999. A plethora of lesion-replicating DNA polymerases. Genes \& Dev. 13: 2191-2195.

Yelamos, J., Klix, N., Goyenechea, B., Lozano, F., Chui, Y.L., Gonzalez Fernandez, A., Pannell, R., Neuberger, M.S., and Milstein, C. 1995. Targeting of non-Ig sequences in place of the V segment by somatic hypermutation. Nature 376: 225 229.

Yuan, F., Zhang, Y., Rajpal, D.K., Wu, X., Guo, D., Wang, M., Taylor, J.S., and Wang, Z. 2000. Specificity of DNA lesion bypass by the yeast DNA polymerase $\eta$. J. Biol. Chem. 275: 8233-8239. 


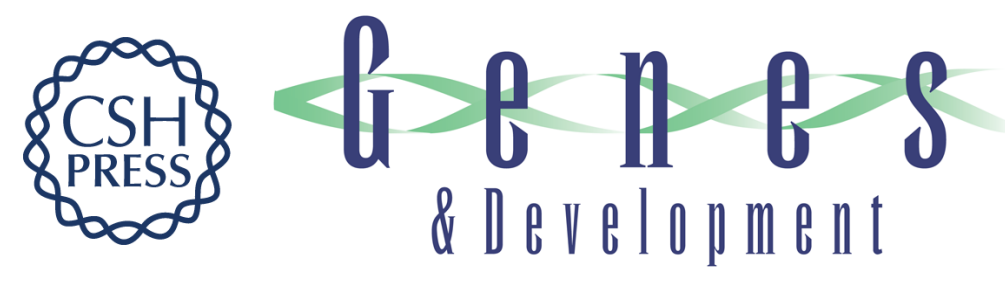

\section{polt, a remarkably error-prone human DNA polymerase}

Agnès Tissier, John P. McDonald, Ekaterina G. Frank, et al.

Genes Dev. 2000, 14:

Access the most recent version at doi:10.1101/gad.14.13.1642

References This article cites 61 articles, 37 of which can be accessed free at: http://genesdev.cshlp.org/content/14/13/1642.full.html\#ref-list-1

License

Email Alerting Receive free email alerts when new articles cite this article - sign up in the box at the top Service right corner of the article or click here.

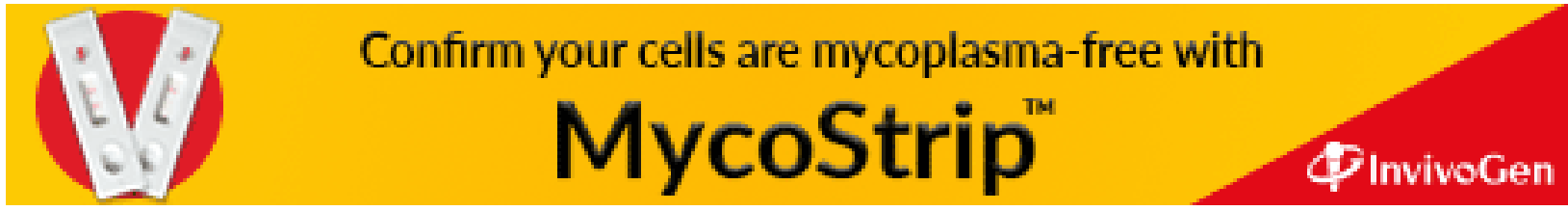

